\title{
Body size structure, biometric relationships and density of Chiton albolineatus (Mollusca: Polyplacophora) on the intertidal rocky zone of three islands of Mazatlan Bay, SE of the Gulf of California
}

Distribución de tamaños corporales, relaciones biométricas y densidad de Chiton albolineatus

(Mollusca: Polyplacophora) en el litoral rocoso de tres islas de la Bahía de Mazatlán, SE del Golfo de California

\section{Luis Miguel Flores-Campaña ${ }^{1}$, Juan Francisco Arzola-González ${ }^{1}$ and Ramón de León-Herrera ${ }^{1,2}$}

\begin{abstract}
${ }^{1}$ Facultad de Ciencias del Mar, Universidad Autónoma de Sinaloa, Paseo Claussen S/N, Apartado Postal 610, Mazatlán, Sinaloa, C.P. 82000, México. lcampana@uas.edu.mx

${ }^{2}$ Programa de Posgrado en Ciencias del Mar y Limnología, Universidad Nacional Autónoma de México, Unidad Académica Mazatlán, Av. Joel Montes Camarena S/N, Apartado Postal 811, Mazatlán, Sinaloa, C.P. 82040, México
\end{abstract}

\begin{abstract}
Resumen.- Las poblaciones del molusco poliplacóforo Chiton albolineatus fueron estudiadas en 6 sitios con diferente acción del oleaje en el litoral rocoso de 3 islas de la bahía de Mazatlán, en el sureste del golfo de California. Esta especie de quitón es endémico de las costas mexicanas del Pacífico. Para determinar sus patrones demográficos basados en su densidad y tamaño corporal se realizaron muestreos en sitios expuestos y protegidos al oleaje de la zona intermareal de estas islas de enero a diciembre de 2008. La longitud (L), ancho (B) y altura (H) del cuerpo de los quitones osciló entre 8,3 y $55,1(\bar{X}=28,9 \pm 6,2)$, $3,0-30,4(\bar{X}=14,8 \pm 3,4)$ y $0,9-19,1(\bar{X}=5,0 \pm 1,8) \mathrm{mm}$, respectivamente, y su peso húmedo $(\mathrm{W})$ varió de 0,1 a $10,2 \mathrm{~g}(\mathrm{X}=1,7 \pm 0,9)$. Las relaciones biométricas fueron $\mathrm{B}=0,478(\mathrm{~L})+1,212, \mathrm{H}=0,198(\mathrm{~L})-1,170$ y $\mathrm{H}=0,389$ (B) - 1,277, para los tamaños corporales y $W=0,0002(L)^{2,710}, W=0,0008(B)^{2,743}$ y $W=0,0792(H)^{1,908}$ para el peso. Los valores de la pendiente de la relación longitud-peso significativamente menores de 3 indican que esta especie tiene un crecimiento alométrico negativo. Su densidad media, entre 0,1 a $2,9 \mathrm{org} . \mathrm{m}^{-2}$, fue mayor en el lado expuesto al oleaje de cada isla posiblemente por una menor presión de depredación que en el lado protegido, mientras que su tamaño corporal fue mayor en el lado expuesto de 2 islas. Esto podría ser interpretado como resultado de la migración desde los sitios protegidos de la acción del oleaje, donde los individuos más pequeños tienen más probabilidades de supervivencia que en las áreas expuestas.
\end{abstract}

Palabras clave: Dimensiones corporales, quitones, exposición al oleaje, islas del Pacífico Mexicano

Abstract.- Populations of the polyplacophoran mollusk Chiton albolineatus were studied at 6 sites with different wave exposure of the rocky shores of 3 islands of Mazatlan Bay (southeastern side of the Gulf of California). This chiton species is endemic to the Mexican Pacific coast. Chitons were sampled on wave-exposed and wave-protected sites in the intertidal zone of these islands from January to December 2008 to determine its demographic patterns based on density and body size. Length (L), breadth (B) and height $(H)$ of chiton body ranged between 8.3 and $55.1(\bar{X}=28.9 \pm 6.2), 3.0-30.4(\bar{X}=14.8 \pm 3.4)$ and 0.9-19.1 ( $\bar{X}$ $=5.0 \pm 1.8) \mathrm{mm}$, respectively, and their wet weight $(\mathrm{W})$ varied from 0.1 to $10.2 \mathrm{~g}(\bar{X}=1.7 \pm 0.9)$. The biometric relationships were $B=0.478(\mathrm{~L})+1.212, \mathrm{H}=0.198(\mathrm{~L})-1.170$ and $\mathrm{H}=0.389(\mathrm{~B})-1.277$, for size and $\mathrm{W}=0.0002$ $(\mathrm{L})^{2.710}, \mathrm{~W}=0.0008(\mathrm{~B})^{2.743}$ and $\mathrm{W}=0.0792(\mathrm{H})^{1.908}$ for weight. The value of the slope of the length-weight relationship was significantly lower than 3 , which indicates negative allometric growth. Average densities ranged from 0.1 to $2.9 \mathrm{org} . \mathrm{m}^{-2}$ and were higher in the exposed sites than in the protected sites of each island, possibly because of a lower predation pressure in areas exposed to high wave energy than in sheltered areas, while its body size were larger in the exposed sites of two islands. This could be interpreted as a result of migration from sites protected from the wave action, where survival of smaller individuals is more likely than in exposed areas.

Key words: Body size, chitons, wave exposure, Mexican Pacific islands 


\section{INTRODUCTION}

Chitons can be abundant mollusks in the intertidal and upper sublittoral zone of rocky shores and coral reefs (Hyman 1967, Slieker 2000, Kaas et al. 2006, Eernisse et al. 2007), but little is known about their spatial distribution, abundance and population size-structure. Additionally, information on factors such as topography, tidal height and wave exposure, that may affect their ecology and limit their distributions, is only available for a few species (Andrus \& Legard 1975, Otaíza \& Santelices 1985, Smith \& Otway 1997, Harper \& Williams 2001, Kelaher \& Cole 2005, Jörger et al. 2008).

Historically, studies of the chiton assemblages of the Mexican Pacific coast have been focused on their taxonomy, distribution and species diversity (Keen 1971, Ferreira 1983, Reyes-Gómez \& Salcedo-Vargas 2002, Reyes-Gómez 2004, García-Ríos \& Álvarez-Ruíz 2007, Reyes-Gómez et al. 2010) but, with the exception of some studies concerning the populations of Chiton articulatus (Sowerby, 1832) in the Acapulco area, Socorro Island in the Revillagigedo Archipelago, and Pajaros and Venados Islands in the Bay of Mazatlan (Rojas-Herrera 1998, Holguin-Quiñones \& Michel-Morfin 2002, FloresCampaña et al. 2007a), the autoecology of most chitons of this region is poorly known.
The species Chiton albolineatus Broderip y Sowerby, 1829 is endemic to the Mexican East Pacific. It is common in the intertidal to shallow subtidal of islands of the southeastern part of the Gulf of California (FloresCampaña et al. 2007b), and it is distributed in a restricted area along the western coast of Mexico, from Mazatlan southwards, down to Acapulco (Keen 1971, Kass et al. 2006). As far as we are aware, no information has been published on the general ecology and population structure of this species. This paper aims to determine demographic patterns based on density and body sizes of C. albolineatus of sheltered and exposed intertidal rocky shores of 3 islands located in the southeastern Gulf of California.

\section{Materials AND MEthodS}

\section{STUDY SITE}

The study was conducted in 3 islands (Pajaros, Venados and Lobos) located in the southeastern part of the Gulf of California, between $23^{\circ} 13^{\prime} 20^{\prime \prime}, 23^{\circ} 15^{\prime} 17^{\prime \prime} \mathrm{N}$ and $106^{\circ} 27^{\prime} 59^{\prime \prime}, 106^{\circ} 28^{\prime} 41^{\prime \prime} \mathrm{W}$. The islands are rocky formations of volcanic origin with thin layers of soil and semi-weathered rocky terrain, facing the city of Mazatlan (Fig. 1).

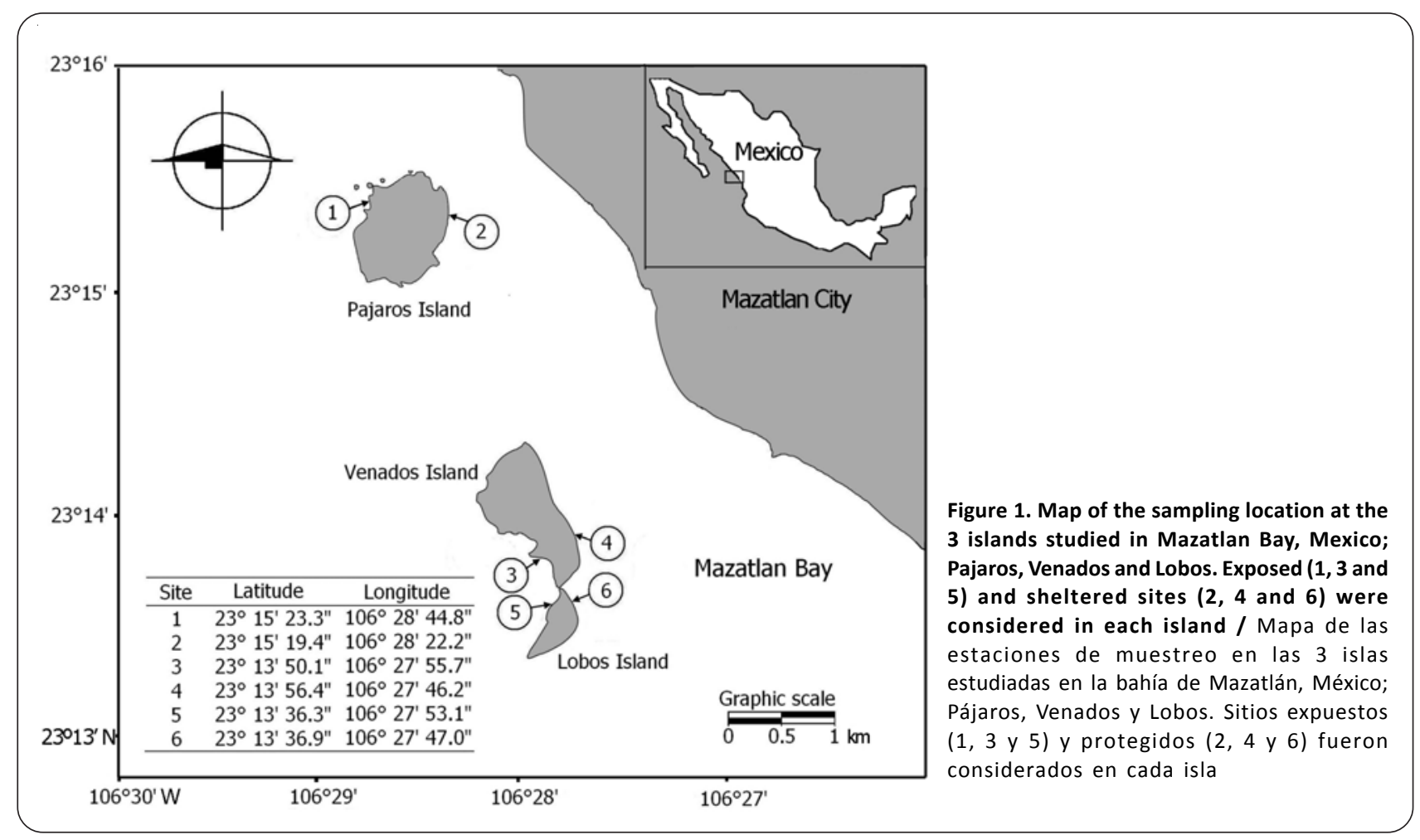


The intertidal area of these islands is narrow (5-15 m, depending on sites) and presents a variety of microenvironments as cliffs, flattened platform, intertidal pools, boulder fields and stones and cracks and crevices in rocks where Chiton albolineatus was collected. The exposed side features strong surf and abrupt topography, while the sheltered side has low wave energy and gently sloping small beaches, particularly on Pajaros and Venados islands.

\section{SPECIES}

Chiton albolineatus is easy to recognize because of its coloration pattern: dark and light olive green colour on central areas, with two longitudinal white lines on mucronal area; lateral areas with numerous white transverse zigzag lines and gray girdle (Reyes-Gómez et al. 2010). It has been recorded from Venados Island and other sites along the Mazatlan coastline, as well as in Isla Tres Marias, Manzanillo, Bahía Santiago and Acapulco (Reyes-Gomez 2004) and Huatulco Bays where it was found on living coral at a depth of $2 \mathrm{~m}$, associated with Stenoplax limaciformis (Sowerby, 1832) (Reyes-Gómez et al. 2010).

Chiton albolineatus inhabits lower to medium rocky intertidal zones of Pajaros, Venados and Lobos Islands. During low tide it is commonly found under boulders, rocks and stones on both sides of Lobos and in the exposed side of Venados, as well as in depressions occupied by the sea urchin Echinometra vanbrunti, in the intertidal belt of the protected side of Venados (underneath the sea urchin, possibly for protection). Sometimes found also in cracks and crevices of rocky intertidal zones of these islands. On temperate and tropical shores, chitons usually remain hidden under a rock or wedged into a depression by day, and forage by night when visual predators are not a threat (Eernisse 2007).

Rich populations of Chiton albolineatus can be found on rocky shores associated with other chitons, such as Stenoplax limaciformis, Radsiella muscaria (Gould, 1846), Tonicia forbesii Carpenter, 1857 and Chiton articulatus in Pajaros, Venados and Lobos Islands (Flores-Campaña et al. 2007b). Other species of this assemblage on the intertidal rocky zone of Pajaros, Venados and Lobos Islands are predators, such as the gastropods Plicopurpura pansa (Gould, 1853), Thais speciosa (Valenciennes, 1832), T. triangularis (Blainville, 1832) and T. biserialis (Blainville, 1832). Other mollusks, conspicuous because of their abundance, are Littorina aspera Philippi, 1846, Nerita funiculata Menke, 1851, N. scabricosta Lamarck, 1822, Collisella acutapex (Berry, 1960) and Mytella guyanensis (Lamarck, 1819) (GonzálezMedina et al. 1999). Common crustaceans in this area are Calcinus californiensis Bouvier, 1898, Grapsus grapsus (Linnaeus, 1758), Pachygrapsus transversus (Gibbes, 1850) and Coenobita compressus H. Milne-Edwards, 1837 (González-Medina et al. 1999, Peñuelas-Román 2002).

Due to its large size and because it is easily accessible, Chiton articulatus, known as 'marine cockroach' or ‘dog's tongue' is the only chiton exploited for human consumption along the Pacific coast of Mexico (ReyesGómez \& Salcedo-Vargas 2002). In Mazatlan, where it reaches body lengths of up to $86 \mathrm{~mm}$ and population densities of 7.9 animals $\mathrm{m}^{-2}$, it is caught in various sites of the intertidal rocky shores, including Pajaros, Venados and Lobos Islands (Flores-Campaña et al. 2007a, JímenezDíaz 2009). In contrast, although it may reach a relatively large size, C. albolineatus is not exploited due to its rather small foot (Reyes-Gómez et al. 2010).

\section{SAMPLING}

From January to December 2008, the population density of Chiton albolineatus were estimated visually during the lowest low tides of each month, on both the exposed (stations 1, 3 and 5) and sheltered (stations 2, 4, and 6) sites of each of island. Living specimens detected within a transect of $50 \mathrm{~m}^{2}$ (Holguín-Quiñones \& Michel-Morfin 2002), marked by two 25-m strings enclosing a 2-m sampling swath in the intertidal zone at 2-3 $\mathrm{m}$ of the water line and parallel to the coastline, were counted by 2 teams of 3-4 people each. This was carried out during the nearly $2 \mathrm{~h}$ of the low tide period, within a time span of 30-35 min at each sampling station.

The density (org. $\mathrm{m}^{-2}$ ) of Chiton albolineatus in each transect was determined in February, March, October, November and December, since the lowest low tides were at night in the other months. Since we observed that the distribution of chitons is patchy, the number of patches (aggregation of chitons) and of the specimens in the largest patch were recorded.

Each month, a sample of $10-20 \%$ of the chitons observed in each transect was obtained at random for size measurements (Holguín-Quiñones \& Michel-Morfin 2002). The actual number collected in each case was decided by the ledger-keeping team member, halfway through the sampling of each transect. As to patches, each sample was proportional to the size of each patch. 
The total number obtained through the sampling period was 1371 . All chitons observed, as well as those collected, were found inactive, under rocks and stones.

Their body length (L), breadth (B) and height $(\mathrm{H})$ were measured with a digital caliper $( \pm 0.1 \mathrm{~mm})$, and the individual wet weight (W), including shell, was obtained with a digital balance $( \pm 0.1 \mathrm{~g})$. Length was determined as the major distance between the front and the posterior parts of the extended body, breadth was measured from side to side of the belt between the fourth and fifth plate, and height was from the bottom of the foot to the dorsal region of the fourth and fifth plate. Measurements in chitons are not as for other mollusks, because they include shell dimensions as well as muscle girdle (Baxter 1982, Baxter \& Jones 1986).

\section{Data Analysis}

Body length was used for size-frequency histograms, using size intervals of $2 \mathrm{~mm}$ (Flores-Campaña et al. 2007a). Body length, breadth, height and weight were used to calculate their respective relationships. The relationships between size parameters were adjusted to the linear model $\mathrm{L}=\mathrm{a}+\mathrm{bH}$, and the potential model $\mathrm{W}=\mathrm{a}(\mathrm{L})^{\mathrm{b}}$ was used for size and weight (Ricker 1975). The constant (b) of the relation size-weight was compared to the theoretical value (3) for isometric growth with a Student's t test.

The variances of the 4 size measurements were homogeneous, but the data distribution was not normal (Bartlett's and Lilliefors' tests, respectively). Therefore, the median values of length, breadth, height and wet weight determined for each station were compared using Kruskal-Wallis and Dunn's multiple comparison tests. The data of population density of each sampling station were normal and homoscedastic, and were compared using one ANOVA for repeated observations test. The level of significance was $\alpha=0.05$ for all tests (Zar 1999).

\section{RESULTS}

\section{SIZE STRUCTURE}

The mean length was $28.9 \pm 6.2 \mathrm{~mm}$, from a minimum of 8.3 to a maximum of $55.1 \mathrm{~mm}$. Breadth ranged from 3.0 to 30.4 $\mathrm{mm}$, with a mean value of $14.8 \pm 3.4 \mathrm{~mm}$. Mean height was $5.0 \pm 1.8 \mathrm{~mm}$ (minimum and maximum: 0.9 and $19.1 \mathrm{~mm}$, respectively). Wet weights varied between 0.1 and $10.2 \mathrm{~g}$, and the mean value was $1.7 \pm 0.9 \mathrm{~g}$ (Table 1 ).

The higher length values (13.3 to $54.9 \mathrm{~mm} ; \overline{\mathrm{X}}=38.4 \pm$ $8.8 \mathrm{~mm}$ ) were recorded in the exposed site of Pajaros. The sheltered site of Pajaros and Lobos and the exposed site of Venados had intermediate sizes: 12.3 to $41.0 \mathrm{~mm}(\overline{\mathrm{X}}=$ $28.4 \pm 6.3)$; 8.3 to $55.1 \mathrm{~mm}(\overline{\mathrm{X}}=31.3 \pm 6.2)$ and 14.0 to 40.2 $\mathrm{mm}(\overline{\mathrm{X}}=28.8 \pm 4.4)$, respectively. Smaller sizes were recorded in sheltered site of Venados ( 9.9 to $44.4, \bar{X}=24.2$ $\pm 5.4 \mathrm{~mm}$ ) and exposed site of Lobos (8.3 to 55.1, $\bar{X}=22.6$ $\pm 6.0 \mathrm{~mm}$ ) (Fig. 2). There were significant differences in length, breadth, height and wet weight distributions between most sampling stations (Kruskal-Wallis and Dunn's tests, $\mathrm{H}$ statistic ranging from 365.91 to $462.68, P$ $<0.001$ for all variables tested).

Table 1. Minimum (Min), maximum (Max), mean and standard deviation (s.d.) values of length, breadth, height and weight of Chiton albolineatus recorded at Pajaros, Venados and Lobos Islands of Mazatlan Bay (Mexico), in 2 sites each: ES, exposed site; and SS, sheltered site / Valores mínimos (Min), máximos (Max), promedio y desviación estándar (s.d.) de la longitud, ancho, altura y peso del Chiton albolineatus registrados en las islas Pájaros, Venados y Lobos de la bahía de Mazatlán (México), en 2 sitios de cada isla: ES, sitio expuesto, y SS, sitio protegido

\begin{tabular}{|c|c|c|c|c|c|c|c|c|c|c|c|c|c|c|c|c|c|c|}
\hline \multirow[t]{2}{*}{ Islands } & \multirow[t]{2}{*}{ Sites } & \multirow[t]{2}{*}{$n$} & \multicolumn{4}{|c|}{ Length (mm) } & \multicolumn{4}{|c|}{ Breadth $(\mathrm{mm})$} & \multicolumn{4}{|c|}{ Height (mm) } & \multicolumn{4}{|c|}{ Weight (g) } \\
\hline & & & Min & $\operatorname{Max}$ & Mean & s.d. & Min & $\operatorname{Max}$ & Mean & s.d. & Min & Max & Mean & s.d. & Min & $\operatorname{Max}$ & Mean & s.d. \\
\hline \multirow[t]{2}{*}{ Pajaros } & ES & 188 & 13.3 & 54.9 & $38.4 \mathrm{a}$ & 8.8 & 7.8 & 30.4 & $19.8 \mathrm{a}$ & 4.2 & 2.1 & 13.8 & $6.9 \mathrm{a}$ & 2.2 & 0.2 & 10.2 & $3.7 \mathrm{a}$ & 2.0 \\
\hline & SS & 92 & 12.3 & 41.0 & $28.4 b c$ & 6.3 & 4.0 & 21.0 & $14.2 \mathrm{~b}$ & 3.7 & 1.2 & 7.9 & $4.9 \mathrm{~b}$ & 1.6 & 0.1 & 4.1 & $1.6 \mathrm{~b}$ & 0.8 \\
\hline \multirow[t]{2}{*}{ Venados } & ES & 345 & 14.0 & 40.2 & $28.8 \mathrm{c}$ & 4.4 & 4.0 & 22.0 & $14.7 \mathrm{~b}$ & 3.9 & 2.2 & 19.1 & $5.6 \mathrm{~b}$ & 2.6 & 0.1 & 3.5 & $1.6 \mathrm{~b}$ & 0.6 \\
\hline & SS & 222 & 9.9 & 44.4 & $24.2 \mathrm{~d}$ & 5.4 & 4.6 & 26.8 & $12.5 \mathrm{c}$ & 2.7 & 1.1 & 7.4 & $4.0 \mathrm{c}$ & 1.2 & 0.1 & 2.0 & $0.9 \mathrm{c}$ & 0.5 \\
\hline \multirow[t]{2}{*}{ Lobos } & ES & 233 & 8.3 & 55.1 & $22.6 \mathrm{~d}$ & 6.0 & 3.0 & 19.2 & $11.6 \mathrm{~d}$ & 2.9 & 0.9 & 13.2 & $3.6 \mathrm{c}$ & 1.5 & 0.1 & 2.4 & $0.8 \mathrm{c}$ & 0.5 \\
\hline & SS & 291 & 13.2 & 47.3 & $31.3 b$ & 6.2 & 3.9 & 24.5 & $16.1 \mathrm{~b}$ & 3.2 & 1.7 & 16.8 & $5.2 \mathrm{~b}$ & 1.5 & 0.1 & 5.3 & $1.8 \mathrm{~b}$ & 1.0 \\
\hline
\end{tabular}

Kruskal-Wallis test $\quad \mathrm{H}=459.46 P<0.001 \quad \mathrm{H}=403.67 \quad P<0.001$

$\mathrm{H}=365.91 P<0.001$

$\mathrm{H}=462.68 P<0.001$

*Different letters in mean values indicate significant differences in length, breadth, height and weight, among sites (Dunn's multiple comparison test) 

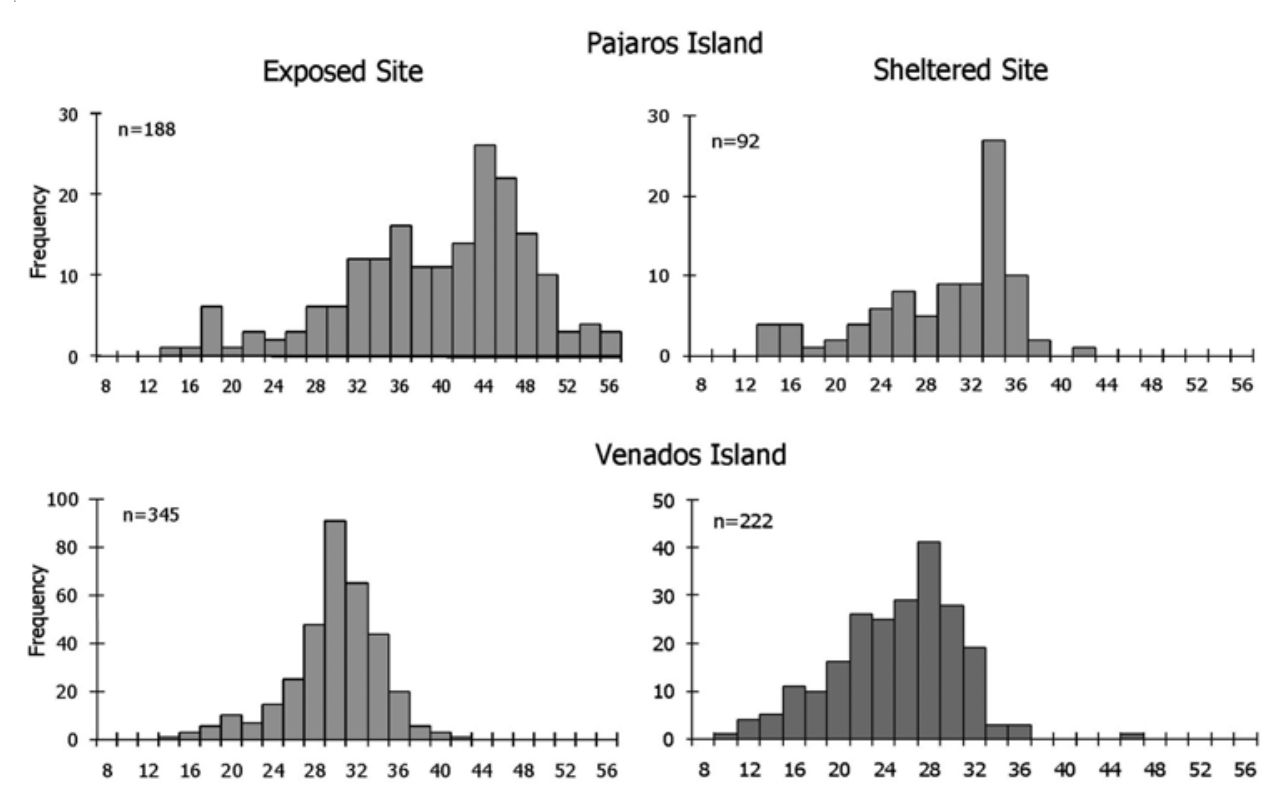

\section{Lobos Island}
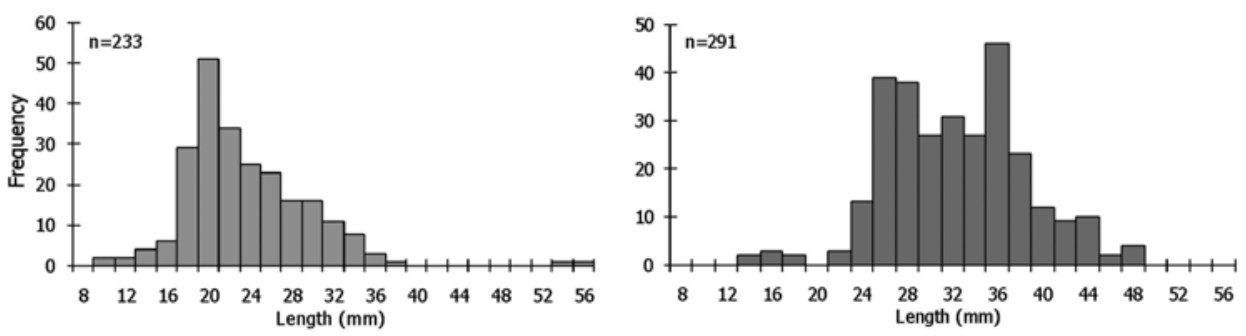

Figure 2. Body length frequency histograms of Chiton albolineatus at 6 sites sampled on Pajaros, Venados and Lobos Islands of Mazatlan Bay, Mexico / Histogramas de frecuencia de la longitud corporal de Chiton albolineatus en los 6 sitios muestreados en las islas Pájaros, Venados y Lobos de la bahía de Mazatlán, México

\section{BIOMETRIC RELATIONSHIPS}

All the biometric relationships among sizes and between size and weight obtained gave a determination coefficient $\left(\mathrm{R}^{2}\right)$ ranging from 0.816 to 0.887 . The values of the slope of size vs. weight relationships were 1.9 in the case of height and 2.7 when length and breadth were used (Table 2 ). In all cases the value of the slope was significantly lower than the theoretical value for isometric growth $(\mathrm{t}=$ 8.72 for length-weight, $\mathrm{t}=7.98$ for breadth-weight and $\mathrm{t}=$ 47.43 for height-weight; $P<0.001$ ).

\section{RELATIVE DENSITY}

The highest and lowest densities (9.18 and 0.1 org. $\mathrm{m}^{-2}$ ) corresponded to the exposed site of Venados Island and the sheltered site of Pajaros, respectively. The average
Table 2. Equations of biometric relationships of Chiton albolineatus, and variance explained in each case $\left(R^{2}\right)$, studied in 3 islands presents in Mazatlan Bay, Mexico; Pajaros, Venados and Lobos. Total number of specimens = $\mathbf{1 3 7 1} /$ Ecuaciones de las relaciones biométricas de Chiton albolineatus, y varianza explicada en cada caso $\left(R^{2}\right)$, estudiada en 3 islas presentes en la bahía de Mazatlán, México; Pájaros, Venados y Lobos. Número total de especímenes $=1371$

\begin{tabular}{lcc}
\hline Relationship & Equation & $\mathrm{R}^{2}$ \\
\hline Length-Height & $\mathrm{H}=0.1985 \mathrm{~L}-1.1701$ & 0.8257 \\
Length-Breadth & $\mathrm{B}=0.4777 \mathrm{~L}+1.2121$ & 0.8870 \\
Height-Breadth & $\mathrm{H}=0.3891 \mathrm{~B}-1.2775$ & 0.8163 \\
Length-Weight & $\mathrm{W}=0.0002 \mathrm{~L}^{2.7097}$ & 0.8776 \\
Breadth-Weight & $\mathrm{W}=0.0008 \mathrm{~B}^{2.7428}$ & 0.8700 \\
Height-Weight & $\mathrm{W}=0.0792 \mathrm{H}^{1.9085}$ & 0.8334 \\
\hline
\end{tabular}


densities ranged from 0.16 to 2.87 org. $\mathrm{m}^{-2}$, with a combined average value for the six sampling sites of 0.96 org. $\mathrm{m}^{-2}$ (Table 3).

Maximum density of 106 org. $\mathrm{m}^{-2}$ was observed in small sections along the transect on the exposed site of Venados. Additionally, the number of individual aggregations (patches) was higher in the exposed than in the sheltered side of each island, and varied from 3 in the protected site of Pajaros to 30 in the exposed site of Venados. With the exception of the sheltered site of Pajaros and the exposed site of Venados, the number of specimens in individual aggregations ranged from 10 to 26 and there were significant differences among most mean densities values of each island except Pajaros (repeated measurements ANOVA, using a significant level of 0.05).

\section{Discussion}

This is the first study to provide information on Chiton albolineatus size distribution. There are only sporadic records of its body length (Keen 1971, Kass et al. 2006, Reyes-Gómez et al. 2010). The size range (8.3 to $55.1 \mathrm{~mm}$ in length) obtained in these islands is wider than the range known for this species, since Keen (1971) mentions that common lengths for adults of this species range from 25 to $40 \mathrm{~mm}$. Kass et al. (2006) and Reyes-Gómez et al. (2010) suggest that these values correspond to medium sized specimens. The largest specimen on record appears to be one reported by Kass et al. (2006), with $43 \mathrm{~mm} \mathrm{~L}$.
There was no previous information on the biometric relations for Chiton albolineatus, although similar equations were given for the length-weight relationship of C. articulatus in the Acapulco area and Socorro Island (Rojas-Herrera 1998, Holguin-Quiñones \& Michel-Morfin 2002) and between sizes (length, breadth and height) and sizes-weight on Pajaros and Venados Islands of Mazatlan Bay (Flores-Campaña et al. 2007a).

The values of the slope of the size-weight relationships were significantly lower than the theoretical value of 3 for isometric growth. This indicates a negative allometric growth, and the most likely explanation for the remarkably low value in the case of height-weight is the habitat of Chiton albolineatus, which is commonly located under rocks and stones during low tide and has therefore limited space available for vertical growth. This coincides with its description, as a moderately elevated to somewhat flattened species (Kass et al. 2006, Reyes-Gómez et al. 2010).

Allometry has been sparsely documented in polyplacophorans, and the scarce information available, such as that for Lepidochitona cinereus (Linnaeus, 1767) (Baxter 1982) and Tonicella marmorea (Fabricius, 1780) (Baxter \& Jones 1986) indicate that in the case of chitons any size study should consider the wide variability of the whole animal measurements in comparison to those of gastropods and bivalves: since they include both the shell dimensions and the muscular girdle, variability may

\begin{tabular}{|c|c|c|c|c|c|c|c|c|}
\hline \multirow[t]{2}{*}{ Island } & \multirow[t]{2}{*}{ Site } & \multirow[t]{2}{*}{$n$} & \multicolumn{4}{|c|}{ Density (org. $\mathrm{m}^{-2}$ ) } & \multirow{2}{*}{$\begin{array}{c}\text { Number of } \\
\text { patches }\end{array}$} & \multirow[t]{2}{*}{ Max /patch } \\
\hline & & & Min & Max & Mean & s.d. & & \\
\hline \multirow[t]{2}{*}{ Pajaros } & ES & 76 & 0.36 & 0.74 & $0.30 \mathrm{~d}$ & 0.31 & 5 & 14 \\
\hline & SS & 32 & 0.08 & 0.42 & $0.16 \mathrm{~d}$ & 0.13 & 3 & 5 \\
\hline \multirow[t]{2}{*}{ Venados } & ES & 718 & 0.44 & 9.18 & $2.87 \mathrm{a}$ & 3.57 & 30 & 106 \\
\hline & SS & 144 & 0.18 & 1.08 & $0.58 \mathrm{c}$ & 0.35 & 10 & 10 \\
\hline \multirow[t]{2}{*}{ Lobos } & ES & 285 & 1.12 & 2.98 & $1.14 \mathrm{~b}$ & 1.24 & 24 & 26 \\
\hline & SS & 184 & 0.78 & 1.98 & $0.74 \mathrm{c}$ & 0.66 & 15 & 15 \\
\hline
\end{tabular}

*Different letters indicate significant differences between mean density values (ANOVA for repeated observations test, $\alpha=0.05 ; \mathrm{a}>\mathrm{b}>\mathrm{c}>\mathrm{d}$ ) 
be related to differential growth rates of the different components, as well as to the flexibility of the girdle (Baxter \& Jones 1986). Thus, the allometric characteristics of chitons could be the result of a combination of shell shape, differential growth rates and environmental influences that force these organisms to seek protection under stones.

Differences in size of mollusks inhabiting sheltered and exposed rocky shores have been documented in several works, mostly for gastropods, and they have been mostly explained by selective migration due to mean tidal height and wave exposure (Hobday 1995, Tanaka et al. 2002, Ríos-Jara et al. 2004) although in the case of Chiton articulatus of Pajaros and Venados Islands, FloresCampaña et al. (2007a) mentioned that, in addition to these factors, differences in size could also be the result of external factors such as selective predation by tourists, or by fishermen, since this species is locally consumed.

The presence of smaller specimens of Chiton albolineatus in sheltered areas coincide with the observations on Acanthopleura echinata (Barnes, 1824) and Chiton latus Sowerby 1825 (central Chile), with the larger individuals occurring in exposed habitats and the smaller in sheltered areas (Otaiza \& Santelices 1985), which might be interpreted as recruitment areas, where smaller individuals are more likely to survive, whereas in sites exposed to wave action the presence of large individuals might be result of migration from sheltered sites.

On the other hand, larval settlement and colonization of the juveniles of some species of gastropods at a lower level of the intertidal zone, where environmental variability is lower, may be considered more conducive to survival (Lysaght 1944, Saier 2000) than at the higher levels colonized by adults, where the greater exposure is more likely to cause environmental stress (Smith \& Newell 1955, Hobday 1995).

The population density of Chiton albolineatus is lower than that recorded for other chitons. Cyanoplax hartwegii (Carpenter, 1855) reaches 5 org. $\mathrm{m}^{-2}$ in California (Connor 1975) and Ischnochiton dispar (Sowerby, 1832) reaches 214 org. $\mathrm{m}^{-2}$ on the Pacific coast of Costa Rica (Jörger et al. 2008) and in other locations along the Mexican Pacific coast, where Chiton articulatus may reach from 4.2 org. $\mathrm{m}^{-2}$ at the Acapulco seaside (RojasHerrera 1988), up to the $5.3 \mathrm{org}$. $\mathrm{m}^{-2}$ registered by HolguinQuiñones et al. (2002) in Socorro Island, both lower than the 7.9 org. $\mathrm{m}^{-2}$ of these islands (Jiménez-Díaz 2009).
The higher abundance of intertidal species in exposed rather than in protected areas of rocky shores may be explained by the effect of environmental (e.g., coastal currents and waves exposure among others) or biological (e.g., competition, predation) factors. Other environmental factors such as substrate chemistry, granulometry or sedimentation may also have an impact on distribution (Menge \& Branch 2001). In this case, the greater density of Chiton albolineatus observed in the exposed side of each island is possibly related to wave frequency. This would cause an intermittent exposure of the rocky shore, decreasing the efficiency of predators and allowing a greater abundance of grazers (Connell 1975).

Chiton albolineatus is commonly distributed in patches along the rocky coastline of the 3 islands at low tide. In fact, the clustered distribution is relatively common in mollusks on rocky intertidal shores and it is a consistent pattern in some chiton species, irrespective of their average abundance (Grayson \& Chapman 2004, Jörger et al. 2008). This agrees with the high number of patches and high numbers of specimens in the largest patch, possibly related to the topography of the intertidal rocky shore, since C. albolineatus seeks refuge under boulders and stones at low tide to prevent desiccation or predation, such as we observed on both zones of Lobos and the exposed site of Venados.

The average density and the body sizes of Chiton albolineatus related to wave exposure documented by this study are only indicative of what may be found in other intertidal chiton communities along the Mexican Pacific coast. Further studies at different sites and other chiton species are needed to indicate whether the patterns observed at these islands can be generalized to similar habitats elsewhere in the tropics. Also, more data are needed to reveal overall patterns of the influencing environmental factors on chiton shape and size, on their distribution and abundance allowing a better understanding of chiton ecology in intertidal rocky shores.

\section{ACKnowledgments}

Funds for field work were made available by Fondo Mixto CONACYT-Gobierno del Estado de Sinaloa (Proyecto SIN-2006-C01-37439) and Universidad Autónoma de Sinaloa. Efraín Higuera Angulo, José Ángel González Morayla and Omar Jiménez Díaz helped in the field work. Domenico Voltolina revised the English text. Three anonymous reviewers made helpful comments and suggestions. 


\section{LITERATURE CITED}

Andrus JK \& WB Legard. 1975. Description of the habitats of several intertidal chitons (Mollusca: Polyplacophora) found along the Monterey Peninsula of central California. Veliger 18: 3-8.

Baxter JM. 1982. Allometric and morphological variations of whole animal and valve dimensions in the chiton Lepidochitona cinereus (L.) (Mollusca: Polyplacophora). Journal of Molluscan Studies 48: 275-282.

Baxter JM \& AM Jones. 1986. Allometric and morphological characteristics of Tonicella marmorea (Fabricius, 1780) populations (Mollusca: Polyplacophora: Ischnochitonidae). Zoological Journal of the Linnean Society 88: 167-177.

Connell JH. 1975. Some mechanisms producing structure in natural communities: a model and evidence from field experiments. In: Cody ML \& JM Diamond (eds). Ecology and evolution of communities, pp. 460-490. Belknap Press, Harvard University, Cambridge.

Connor MS. 1975. Niche apportionment among the chitons Cyanoplax hartwegii and Mopalia muscosa and the limpets Collisella limatula and Collisella pelta under the brown alga Pelvetia fastigiata. Veliger 18: 9-17.

Eernisse DJ. 2007. Chitons. In: Denny MW \& SD Gaines (eds). Encyclopedia of tidepools and rocky shores, pp. 127-133. University of California Press, Berkeley.

Eernisse DJ, RN Clark \& A Draeger. 2007. Polyplacophora. In: Carlton JT (ed). Light and Smith manual: Intertidal invertebrates from Central California to Oregon, pp. 701713. University of California Press, Berkeley.

Ferreira JA. 1983. The genus Chaetopleura Shuttleworth, 1853 in the warm temperate and tropical Eastern Pacific, Southern California to Peru, with the description of two new species. Veliger 25: 203-224.

Flores-Campaña LM, MA González-Montoya, MA OrtizArellano \& JF Arzola-González. 2007a. Estructura poblacional de Chiton articulatus (Sowerby, 1832) en las islas Pájaros y Venados de la bahía de Mazatlán, Sinaloa, México. Revista Mexicana de Biodiversidad 78: 23S-31S.

Flores-Campaña LM, MA Ortíz-Arellano, JF ArzolaGonzález, FJ González-Medina, E Cortez-Acosta \& D Rodríguez-García. 2007b. Los quitones de las islas de la costa de Sinaloa, México. In: Ríos-Jara E, MC EsquedaGonzález \& CM Galván-Villa (eds). Estudios sobre la malacología y conquiliología en México, pp. 43-45. Universidad de Guadalajara, Guadalajara.

García-Ríos CI \& M Álvarez-Ruíz. 2007. Comunidades de quitones (Mollusca: Polyplacophora) de la Bahía de La Paz, Baja California Sur, México. Revista de Biología Tropical 55: 177-182.

González-Medina F, JR Cazares-García, A ZepedaCanizalez \& LA González-Magdaleno. 1999. Inventario faunístico de los moluscos y crustáceos decápodos de la zona intermareal de la isla Lobos, Venados y Pájaros de la bahía de Mazatlán, Sinaloa, México. Tesis Profesional, Facultad de Ciencias del Mar, Universidad Autónoma de Sinaloa, Mazatlán, 89 pp.
Grayson JE \& MG Chapman. 2004. Patterns of distribution and abundance of chitons of the genus Ischnochiton in intertidal boulder fields. Austral Ecology 29: 363-373.

Harper KD \& GA Williams. 2001. Variation in abundance and distribution of the chiton Acanthopleura japonica and associated molluscs on a seasonal, tropical, rocky shore. Journal of Zoology 253(3): 293-300.

Hobday A. 1995. Body-size variation exhibited by an intertidal limpet: Influence of wave exposure. Tidal height and migratory behavior. Journal of Experimental Marine Biology and Ecology 189: 29-45.

Holguin-Quiñones OF \& JE Michel-Morfin. 2002. Distribution, density and length-weigth relationship of Chiton articulatus Sowerby, 1832 (MolluscaPolyplacophora) on isla Socorro, Revillagigedo Archipielago, Mexico. Journal of Shellfish Research 21(1): 239-241.

Hyman LH. 1967. The Invertebrates: Mollusca I. Vol. VI: 1792. McGraw-Hill, New York.

Jiménez-Díaz O. 2009. Variación de las tallas de Chiton articulatus (Sowerby, 1832) durante 2088, en las Tres Islas de la bahía de Mazatlán, Sinaloa. Tesis Profesional, Facultad de Ciencias del Mar, Universidad Autónoma de Sinaloa, Mazatlán, 34 pp.

Jörger KM, R Meyer \& IS Wehrtmann. 2008. Species composition and vertical distribution of chitons (Mollusca: Polyplacophora) in a rocky intertidal zone of the Pacific coast of Costa Rica. Journal of the Marine Biological Association of the United Kingdom 88: 807-816.

Kaas P, RA Van Belle \& HL Strack. 2006. Monograph of living chitons (Mollusca: Polyplacophora). Volume 6, Suborder Ischnochitona (concluded): Schizochitonidae; Chitonidae. Additions to Volumes 1-5, 464 pp. E. Brill / W. Backhuys, Leiden.

Keen MA. 1971. Sea shells of Tropical West America. Marine mollusks from Baja California to Perú, 1065 pp. Stanford University Press, Stanford.

Kelaher BP \& VJ Cole. 2005. Variation in abundance and size structure of populations of the small chiton Acanthochiton retrojecta. Journal of Molluscan Studies 71:145-151.

Lysaght A. 1944. The biology of the gastropod Littorina neritoides (L.) on the Plymouth breakwater. Journal of the Marine Biological Association of the United Kingdom 25: 41-67.

Menge BA \& GM Branch. 2001. Rocky intertidal communities. In: Bertness MD, SD Gaines \& M Hay (eds). Marine community ecology, pp. 221-251. Sinauer Associates, Sunderland.

Otaíza RD \& B Santelices. 1985. Vertical distribution of chitons (Mollusca: Polyplacophora) in the rocky intertidal zone of central Chile. Journal of Experimental Marine Biology and Ecology 86: 229-240. 
Peñuelas-Román MI. 2002. Distribución y abundancia de crustáceos en las islas Lobos, Venados y Pájaros de la bahía de Mazatlán, Sinaloa. Tesis Profesional, Facultad de Ciencias del Mar, Universidad Autónoma de Sinaloa, Mazatlán, 68 pp.

Reyes-Gómez A. 2004. Chitons in Mexican waters. Bollettino Malacologico 5: 69-82.

Reyes-Gómez A \& MA Salcedo-Vargas. 2002. The recent mexican chiton (Mollusca: Polyplacophora) species. Festivus 34: 17-27.

Reyes-Gómez A, NA Barrientos-Lujan, J Medina-Bautista \& S Ramírez-Luna. 2010. Chitons from the coralline area of Oaxaca, Mexico (Polyplacophora). Bollettino Malacologico 46: 111-125.

Ricker WE. 1975. Computation and interpretation of biological statistics of fish population, 382 pp. Department of Environmental Fisheries \& Marine Service, Ottawa.

Ríos-Jara E, CC Hernández-Cedillo, E Juárez-Carrillo \& I Enciso-Padilla. 2004. Variations in density, shell size and growth with shore height and wave exposure of the rocky intertidal snail, Calyptraea spirata (Forbes, 1852), in tropical Mexican Pacific. Journal of Shellfish Research 23: 545-552.
Rojas-Herrera AA. 1998. Análisis biológico-pesquero de la cucaracha de mar (Chiton articulatus Sowerby 1832) de Acapulco, Gro. México. En: Memorias IX Congreso Nacional de Zoología, pp. 151-156. Universidad Juárez Autónoma de Tabasco y Sociedad Mexicana de Zoología, Villahermosa.

Saier B. 2000. Age-dependent zonation of the periwinkle Littorina littorea (L.) in the Wadden Sea. Helgoland Marine Research 54: 224-229.

Slieker FJA. 2000. Chitons of the world: an illustrated synopsis of recent Polyplacophora, 154 pp. L'Informatore Piceno, Ancona.

Smith JE \& GE Newell. 1955. The dynamics of the zonation of the common periwinkle Littorina littorea (L.) on a stony beach. Journal of Animal Ecology 24: 35-56.

Smith KA \& NM Otway. 1997. Spatial and temporal patterns of the abundance and effects of disturbance on underboulder chitons. Molluscan Research 18: 43-57.

Tanaka MO, TEM Duque-Estrada \& CA Magalhaes. 2002. Dynamics of the acmaeid limpet Collisella subrugosa and vertical distribution of size and abundance along a wave exposure gradient. Journal of Molluscan Studies 68(1): 55-64.

Zar JH. 1999. Biostatistical analysis, 663 pp. Prentice-Hall, Upper Saddle River.

Received 25 January 2012 and accepted 14 May 2012

Associate Editor: Gabriela Muñoz C. 